\title{
Life history trait differences in isolated populations of the endangered Red-cockaded Woodpecker
}

\author{
Lacey Williamson ${ }^{1,2, *}$, Victoria Garcia ${ }^{1,3}$ \& Jeffrey R. Walters ${ }^{1}$
}

Received: January 26, 2016-Accepted: March 25, 2016

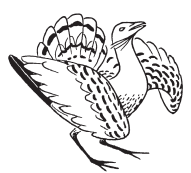

Lacey Williamson, Victoria Garcia \& Jeffrey R. Walters 2016. Life history trait differences in isolated populations of the endangered Red-cockaded Woodpecker. - Ornis Hungarica 24(1): 55-68. Red-cockaded Woodpeckers (Picoides borealis) are cooperative breeders that have specific reproductive habitat needs. We examined three separate sites in the southeastern United States to see how life history traits differed among isolated populations of Red-cockaded Woodpeckers from 1980 to 2013. We examined the life history traits group size, partial brood loss, number of fledglings, lay date, clutch size, and lifespan. Traits differed among sites, suggesting that populations were adapted to local conditions and different life history trade-offs were important under different environmental conditions at each site. At the two coastal sites in Florida and North Carolina, the family group sizes, lifespans, and partial brood loss were higher when compared to the inland site in North Carolina. Clutch size and number fledged were higher at the two northernmost sites when compared to the southern site. Identifying the differences in life history traits can allow more specific and effective management practices.

Keywords: clutch size, cooperative breeder, endangered, lay date, life history, Red-cockaded Woodpecker

Összefoglalás Az életmenet jellemzők változásai a környezethez való adaptációt mutathatnak. A kooperatívan költő kokárdás harkály (Picoides borealis) élőhely-specialista faj. Az Amerikai Egyesült Államok délkeleti részén, három területen vizsgáltuk, hogy az életmenet bizonyos elemei különböznek-e a vizsgált faj izolált populációi között. Az adatokat 1980-2013-ig gyüjtöttük. Az életmenet következő szegmenseit vizsgáltuk: csoportméret, részleges fészekalj-veszteség, a kirepülő fiatalok száma, a tojásrakás dátuma, fészekalj méret és az élettartam. A felsorolt változók területenként eltéréseket mutattak, sugallva, hogy az egyes populációk adaptálódtak a helyi viszonyokhoz, illetve, hogy az egyes életmenet szegmensek különböző súllyal eshetnek latba az egyes területeken. A két tengerparti területen, Floridában és Észak-Karolinában a csoport mérete, az egyedek élethossza és a részleges fészekalj vesztesége magasabb volt a kontinentális észak-karolinai területhez képest. A fészekalj mérete és a kirepült fiatalok száma ezzel szemben magasabb volt a két északi populáció esetében. Az életmenet jellemzők populációk közötti különbségeinek felderítése lehetővé teszi specifikusabb, effektívebb természetvédelmi kezelések alkalmazását.

Kulcsszavak: fészekaljméret, kooperatív költő, veszélyeztetett, tojásrakási dátum, életmenet, kokárdás harkály

${ }^{1}$ Department of Biological Sciences, Virginia Tech, Blacksburg,VA, 24061,USA, email: wacey2@vt.edu

${ }^{2}$ Department of Ecosystem Science and Management, Pennsylvania State University, University Park, PA 16802, USA

${ }^{3}$ Department of Biological Sciences, Old Dominion University, Norfolk, VA, 23529, USA

* corresponding author 


\section{Introduction}

Life history strategies directly affect individual fitness. Examples of key life history traits include clutch size, lifespan, and age at first reproduction (Stearns 1976). Variation in life history traits, such as clutch size, can be determined by factors such as resource availability and environment (Lack 1947). Associations, often negative, between life history traits are referred to as life history trade-offs (Zera \& Harshman 2001). Different life history trade-offs and trait values are selected for in different environments (Linden \& Møller 1989) even within a single species. For example, life history strategies can vary over elevational gradients within species (Bears et al. 2009). The combination of life history trade-offs should result in the highest fitness for individuals under those conditions (Badyaev \& Ghalambor 2001), and these individuals will be better represented than their conspecifics in future generations (Stearns 1976). Therefore, examining life history traits is important both because life history theory is a major branch in ecology and because it can assist in conservation and management efforts.

This study investigated life history trait differences among three populations of endangered Red-cockaded Woodpeckers (Picoides borealis) for which extensive long-term data were available. In the past decade, the majority of studies on Red-cockaded Woodpeckers focused on habitat requirements and preferences over just a few years. Demographic information obtained from studies conducted over longer periods of time can be beneficial for identifying life history traits that should be targeted for management. Since 1980 (Walters et al. 1988), we have monitored three fragmented populations of Red-cockaded Woodpeckers that occur in different locations. These three populations have been managed separately and comparisons among them could reveal differences that can be used to improve sitespecific management techniques. Red-cockaded Woodpeckers occur in isolated populations and face different quality habitats, climates, and management regimes. Better management can be achieved by focusing on the different life history strategies and trade-offs utilized at these fragmented sites. Therefore, assessment of life history traits is essential to understanding how different management techniques are affecting populations.

\section{Methods}

\section{Study species}

Red-cockaded Woodpeckers are cooperative breeders, with $0-4$ helpers assisting a single, monogamous breeding pair in defending territories, raising young, and excavating new cavities (Lennartz et al. 1987). Most helpers are male offspring from previous breeding seasons, but female offspring and unrelated helpers of both sexes also occur (Walters et al. 1988). Red-cockaded Woodpeckers are non-migratory and family groups defend their territories year round. They are a medium-sized woodpecker that eats mostly invertebrates, and clutch sizes vary from 2-5 eggs.

Red-cockaded Woodpeckers inhabit mature, open pine stands throughout the southeastern United States (Schaefer et al. 2004). Due to the reduced use of fire and the cutting of 
old-growth pine forests in the Southeast, the range and numbers of Red-cockaded Woodpecker have declined (Schaefer et al. 2004). Management of Red-cockaded Woodpeckers has focused on improvement of habitat quality to encourage continued use of territories and addition of new territories. Territories are defended areas that contain a woodpecker family group's activities and its borders may be determined by habitat edges or by other woodpecker groups (Ligon 1970). Each territory contains a set of actively used and defended cavity trees termed the cavity tree cluster (Walters et al. 1988, Walters et al. 1992). Red-cockaded Woodpeckers are unique in excavating their cavities exclusively in living pine trees. The presence of high quality cavities has been shown to be a critical component of territory quality (Walters et al. 1992), presumably due to the difficulty and inordinate length of time required to excavate cavities in living pines (James et al. 1997, Harding \& Walters 2004). Accordingly, artificial cavities have been used to maintain (i.e. prevent territory abandonment) and improve (i.e. convert unsuitable habitat to suitable habitat) territories (Walters 1991) with great success.

\section{Study Areas}

In this study, we used long-term demographic data from three isolated study sites: an inland site in the longleaf pine (Pinus palustris) forests of the North Carolina Sandhills (SH), a coastal site of longleaf and loblolly pine (Pinus tueda) at Marine Corps Base Camp Lejeune, NC (MCBCL), and a Gulf Coast Florida panhandle site at Eglin Air Force Base, Florida (EAFB) with extensive longleaf pine sandhills habitat (Map 1). Detailed descriptions of the study areas and habitat can be found as follows: North Carolina Sandhills (Carter et al. 1983, Walters et al. 1988); North Carolina Coastal Plain (Walters et al. 1995, Zwicker \& Walters 1999) and Eglin Air Force Base (Blanc \& Walters 2008).

The inland site (Sandhills, NC) was once dominated by fire-dependent species such as longleaf pines. The other forests are mixed pine and have varying amounts of understory and midstory (Trainor et al. 2013). Data were collected during the breeding seasons (AprilJune) from 1980 to 2013.

\section{Field methods}

The demographic data were obtained by monitoring color-marked birds at each site for up to 32 years: coastal Marine Corps Base Camp Lejeune (1986-2011), inland Sandhills (19802011), and coastal Eglin Air Force Base (1993-2013). For a detailed description of how data were collected, refer to Walters et al. (1988).

Briefly, each year, members of each territory and unaffiliated birds were individually identified by color band combinations and their status (i.e. breeder, helper, floater) was determined (Letcher et al. 1998). All active cavities within a cluster were marked and checked repeatedly during the breeding season for signs of nesting, to age nestlings for banding, and to identify fledglings (Walters et al. 1988). Reproduction was monitored by identifying and counting banded and fledged young in each territory. 


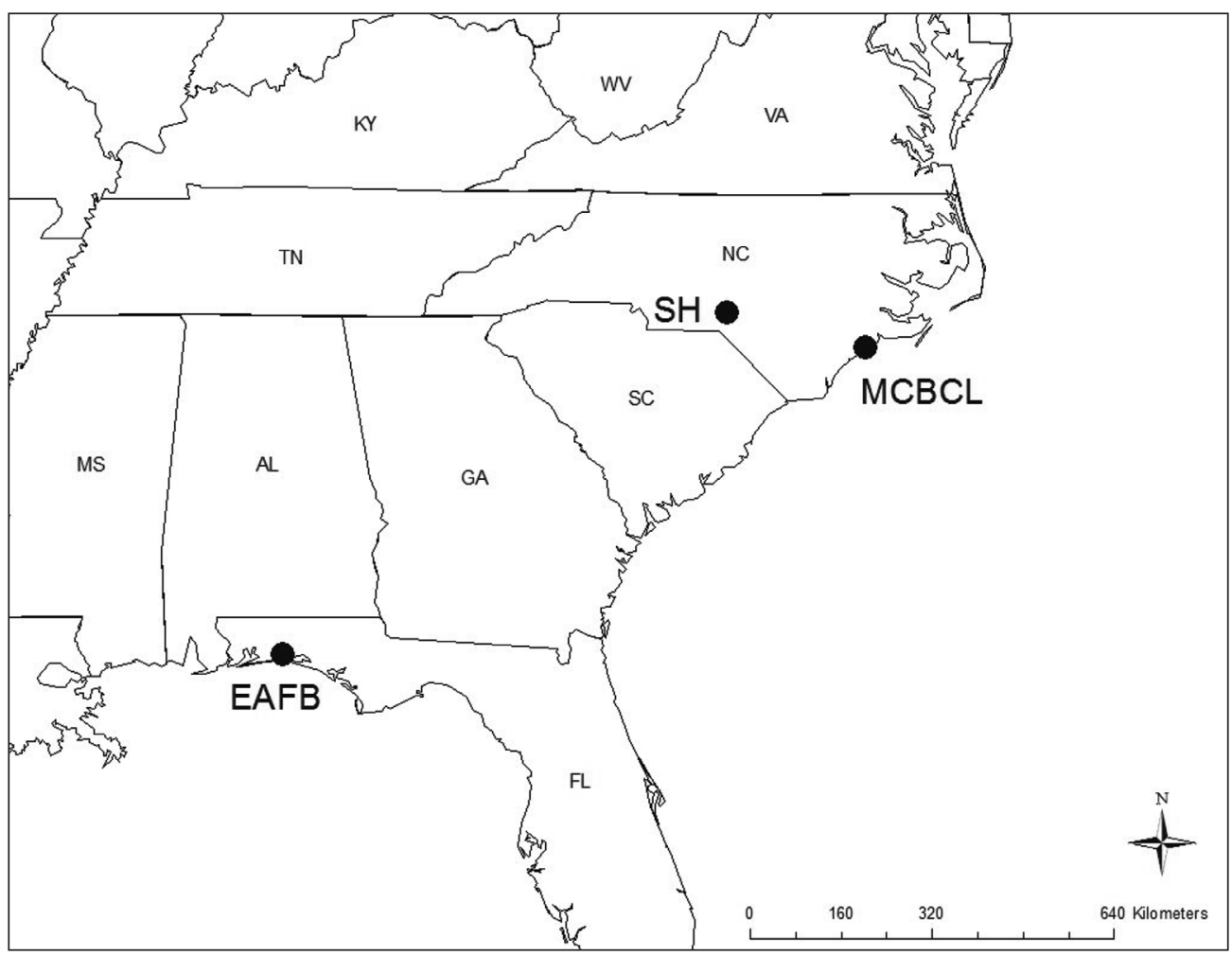

Map 1. Map of the southeastern United States showing the three Red-cockaded Woodpecker study sites: Sandhills (SH), Marine Corps Base Camp Lejeune (MCBCL), Eglin Air Force Base (EAFB)

1. térkép Az Amerikai Egyesült Államok délkeleti részének térképe a vizsgált területekkel: homokdombok $(\mathrm{SH})$, Lejeune haditengerészeti bázis $(\mathrm{MCBCL})$, Eglin légierő bázis (EAFB)

\section{Statistical analyses}

We used Generalized Linear Mixed Models (GLMM), Generalized Linear Models (GLM), and Linear Mixed Models (package lme4) (Bates et al. 2015) in program R (R Core Team 2014) to compare traits among sites. The life history traits that we examined were group size, lifespan, number of fledglings, clutch size, lay date, and brood loss (eggs laid - eggs hatched). To examine lifespan, we only included birds that survived the first year and hatched before 2001, as only $0.7 \%$ (13/1891) of birds hatched before 2001 were still alive in 2013 . For lay date, only the first nesting attempt was used. Red-cockaded Woodpeckers typically only re-nest after nest failure. The Eglin Air Force Base data set lacked information on lay date due to differences in monitoring protocols, and was therefore not included in the analysis. Group size included the breeding pair and adult helpers. Except for lifespan, each response variable was treated as a feature of the group, not of the breeders. Therefore, only one observation per territory was included in the analyses. For each dependent variable, we included the variable Site (Sandhills, Marine Corps Base Camp Lejeune, or Eglin Air Forde Base) to examine differences between study sites. We also included other possible predictor variables (covariates) that could explain 
variation in life history traits in each model as appropriate. The covariates were group size (but not when group size was the response variable), sex, age, and mate's age. We also included the following random effects: individual identity of the male territory holder, territory and microsite. Microsites were groups of territories that were geographically near each other within each study area. We included different random factors in each analysis depending on how the data were structured and which random factors explained $>0$ variance. To limit the number of possible models and to avoid problems with model convergence, we did not examine interactions in this analysis (Hoyt \& Hannon 2002, Montague-Drake et al. 2009). We used a Poisson distribution with a log link for group size, lifespan, number of fledglings, clutch size, and brood loss. We used a Gaussian distribution with an identity link for lay date. We used Akaike's Information Criterion for small sample sizes (AICc) to compare models and to determine if life history traits differed among sites (Burnham \& Anderson 2002, Anderson 2008). We used maximum likelihood estimation for the AIC analyses, but estimates were based on restricted maximum likelihood estimation. We tested saturated GLMMs and GLMs for overdispersion by examining the ratio of the deviance to residual degrees of freedom, but the ratios were $<1$, indicating the data were not overdispersed. All reported estimates and graphs are predicted values for each site from the highest-ranked model and 95\% confidence intervals.

\section{Results}

Overall, there were 41,396 total observations and 4,514 individual birds. Marine Corps Base Camp Lejeune (coastal site) had the lowest number of birds with 6,754 total observations for 565 individual birds. At Eglin Air Force Base (coastal site), there were 835 individual birds and 2,508 observations. The Sandhills site (inland site) was studied for the most years and had 3,114 individual birds and 32,134 total observations.

Group sizes were larger in the two coastal sites (MCBCL 2.88 adults, 95\% CI: 2.79-2.97; EAFB 2.81 adults, 95\% CI: 2.66-2.98) than at the inland site (SH 2.64 adults, 95\% CI: 2.612.68) (Table 1, Figure 1). However, variance at the Eglin site was quite high, with large confidence intervals. Lifespan was longest at Marine Corps Base Camp Lejeune (6.02 years, 95\% CI: 5.72-6.33) and was shorter in the inland Sandhills population (4.63 years, 95\% CI: 4.52-4.74) (Table 2, Figure 2). The Florida population (Eglin Air Force Base) fell in between with a lifespan of 5.21 (95\% CI: 4.30-6.32) years.

Clutch size was significantly larger in the two northern populations (MCBCL 3.41 eggs, 95\% CI: 3.29-3.53; SH 3.31, 95\% CI: 3.26-3.37) than in the more southern Florida population (EAFB; 2.99, 95\% CI: 2.76-3.23) (Table 3, Figure 3). Fledgling production was also significantly higher in the northern populations (SH 1.79 fledglings per breeding male, 95\% CI: 1.75-1.83; MCBCL1.66,95\% CI: 1.58-1.75), compared to the Florida population at Eglin Air Force Base (1.25, 95\% CI: 1.10-1.41) (Table 4, Figure 4). Lay dates were earlier in the inland Sandhills population (Julian date 118, 95\% CI: 117-120) than the coastal Marine Corps Base Camp Lejeune population (125, 95\% CI: 122-128) (Table 5, Figure 5). The coastal sites experienced more brood loss (MCBCL 1.38 eggs lost, 95\% CI: 1.31-1.45; EAFB 1.38 eggs lost, 95\% CI: 1.26-1.51) than the inland Sandhills population (1.12 eggs lost, 95\% CI: 1.09-1.14) (Table 6, Figure 6). 


\begin{tabular}{|r|c|c|c|c|c|}
\hline Model (Group Size) & $K$ & AlCc & Delta_AlCc & LL & Cum.Wt \\
\hline Site + Territory & 4 & 2390.116 & 0 & -1191.06 & 0.999999 \\
\hline Territory & 2 & 2418.464 & 28.347 & -1207.23 & 1 \\
\hline
\end{tabular}

Table 1. Comparison of models examining whether group size differs between study sites in Red-cockaded Woodpeckers $(n=9,620)$. Territory was treated as a random factor. $L L$ is the log likelihood, Cum. Wt is the cumulative Akaike weight of each model

1. táblázat Az egyes vizsgálati területeken rögzített csoportméreteket vizsgáló modellek összehasonlítása a kokárdás harkálynál $(\mathrm{n}=9620)$. A territórium random faktorként volt kezelve. Az LL log likelihood-ot jelent, a Cum. Wt pedig az egyes modellek Akaike (AIC, Akaike információs kritérium) súlyát jelenti

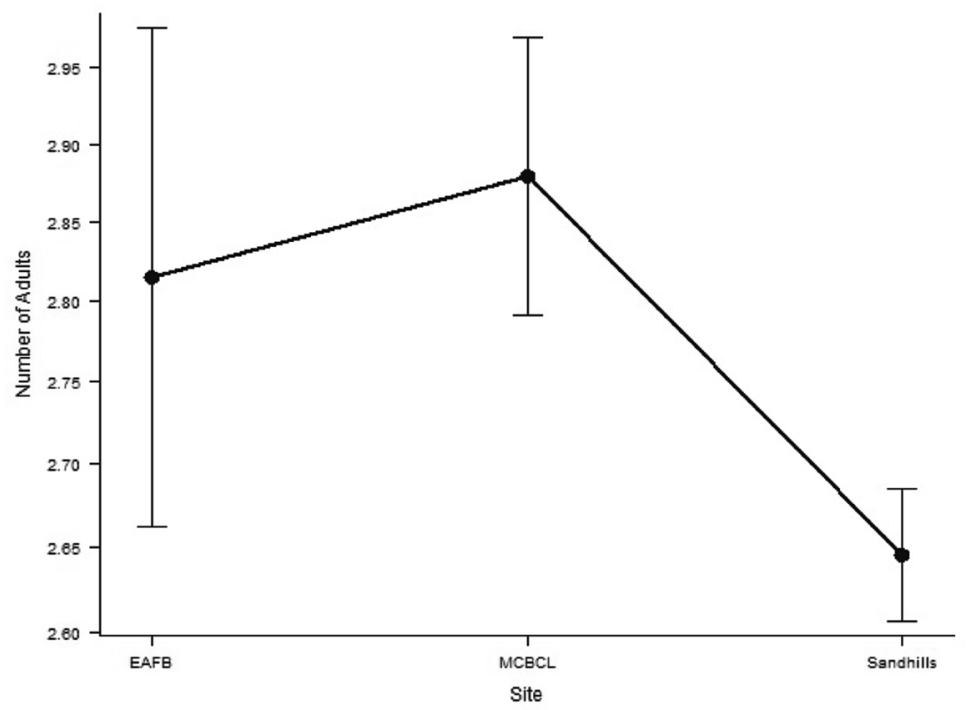

Figure 1. Group sizes (number of adults) were larger at the two coastal sites (Marine Corps Base Camp Lejeune and Eglin Air Force Base) when compared to the inland site (Sandhills). Estimates are predicted values from the highest ranked model with 95\% confidence intervals

1. ábra A csoportméret (adult egyedek száma) a két tengerparti területen nagyobb volt (Lejeune haditengerészeti bázis és Eglin légierő bázis), összehasonlítva a kontinentális vizsgálati területtel (homokdombok). A becslések a lejobbnak értékelt modellből prediktált értékek, 95\%os konfidencia intervallumokkal. A vízszintes tengelyen olvashatók az egyes mintaterületek: Eglin légierő bázis (EAFB), Lejeune haditengerészeti bázis $(\mathrm{MCBCL})$, homokdombok $(\mathrm{SH})$ 


\begin{tabular}{|r|r|r|r|r|c|}
\hline Model (Lifespan) & \multicolumn{1}{|c|}{ K } & \multicolumn{1}{|c|}{ AlCc } & Delta_AICC & \multicolumn{1}{c|}{ LL } & Cum.Wt \\
\hline Site + Mean Group Size + Sex & $\mathbf{5}$ & $\mathbf{8 5 7 9 . 6 6 8}$ & $\mathbf{0}$ & $\mathbf{- 4 2 8 4 . 8 2}$ & $\mathbf{1}$ \\
\hline Mean Group Size + Sex & 3 & 8658.296 & 78.628 & -4326.14 & 1 \\
\hline Site + Mean Group Size & 4 & 9136.866 & 557.198 & -4564.42 & 1 \\
\hline Mean Group Size & 2 & 9228.221 & 648.552 & -4612.11 & 1 \\
\hline Site + Sex & 4 & 9286.221 & 706.553 & -4639.10 & 1 \\
\hline Site & 3 & 9856.622 & 1276.954 & -4925.30 & 1 \\
\hline Sex & 2 & 9881.042 & 1301.374 & -4938.52 & 1 \\
\hline 1 & 1 & 10447.000 & 1867.333 & -5222.50 & 1 \\
\hline
\end{tabular}

Table 2. Comparison of models examining factors that affect Red-cockaded Woodpecker lifespan $(n=2,583)$. All factors were fixed. $L L$ is the log likelihood, Cum. Wt is the cumulative Akaike weight of each model

2. táblázat $A$ kokárdás harkály élettartamát $(n=2583)$ befolyásoló faktorokat vizsgáló modellek öszszehasonlítása. Minden faktor fix volt. Az LL log likelihood-ot jelent, a Cum. Wt pedig az egyes modellek Akaike (AIC, Akaike információs kritérium) súlyát jelenti

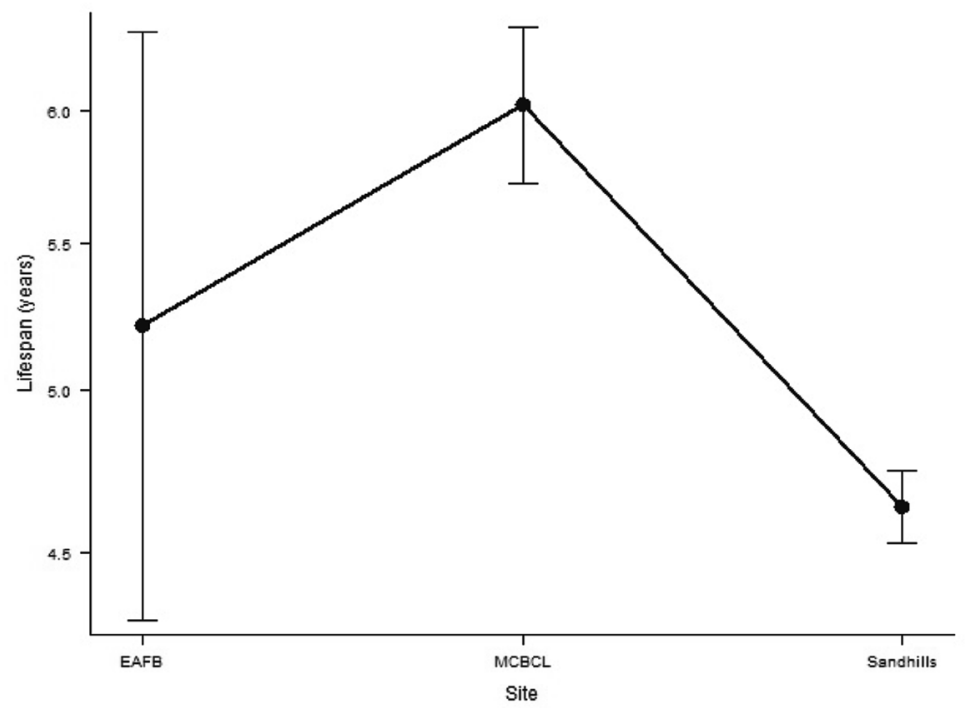

Figure 2. Lifespan was longest at Marine Corps Base Camp Lejeune, and shortest at the inland study site (Sandhills). Estimates are predicted values from the highest ranked model with 95\% confidence intervals

2. ábra Az egyedek élettartama a Lejeune haditengerészeti bázis területén volt a leghosszabb, a legrövidebb pedig a kontinentális területen (homokdombok). A becslések a lejobbnak értékelt modellből prediktált értékek, 95\%-os konfidencia intervallumokkal. A vízszintes tengelyen olvashatók az egyes mintaterületek: Eglin légierő bázis (EAFB), Lejeune haditengerészeti bázis $(\mathrm{MCBCL})$, homokdombok $(\mathrm{SH})$ 


\begin{tabular}{|r|c|c|r|r|c|}
\hline Model (Clutch size) & $K$ & \multicolumn{1}{|c|}{ AlCc } & Delta_AICc & \multicolumn{1}{c|}{ LL } & Cum.Wt \\
\hline Site + Group Size + Age + Bird ID & $\mathbf{6}$ & $\mathbf{1 0 1 8 . 8 8 6}$ & $\mathbf{0}$ & $\mathbf{- 5 0 3 . 4 4}$ & $\mathbf{0 . 9 1 6 0 2 7}$ \\
\hline Group Size + Age + Bird ID & 4 & 1023.925 & 5.039 & -507.96 & 0.989784 \\
\hline Site + Age + Bird ID & 5 & 1027.999 & 9.113 & -508.99 & 0.999401 \\
\hline Age + Bird ID & 3 & 1033.551 & 14.665 & -513.77 & 1 \\
\hline Site + Group Size + Bird ID & 5 & 1053.968 & 35.081 & -521.98 & 1 \\
\hline Group Size + Bird ID & 3 & 1059.220 & 40.334 & -526.61 & 1 \\
\hline Site + Bird ID & 4 & 1070.644 & 51.758 & -531.32 & 1 \\
\hline Bird ID & 2 & 1076.509 & 57.623 & -536.25 & 1 \\
\hline
\end{tabular}

Table 3. Comparison of models examining factors that affect Red-cockaded Woodpecker clutch size $(n=5,428)$. Individual bird identity (Bird ID) was included as a random factor. $L L$ is the log likelihood, Cum. Wt is the cumulative Akaike weight of each model

3. táblázat A kokárdás harkály fészekaljméretét $(n=5428)$ befolyásoló faktorokat vizsgáló modellek összehasonlítása. A madarak egyéni azonosítója (Bird ID) random faktorként volt kezelve. Az LL log likelihood-ot jelent, a Cum. Wt pedig az egyes modellek Akaike (AIC, Akaike információs kritérium) súlyát jelenti

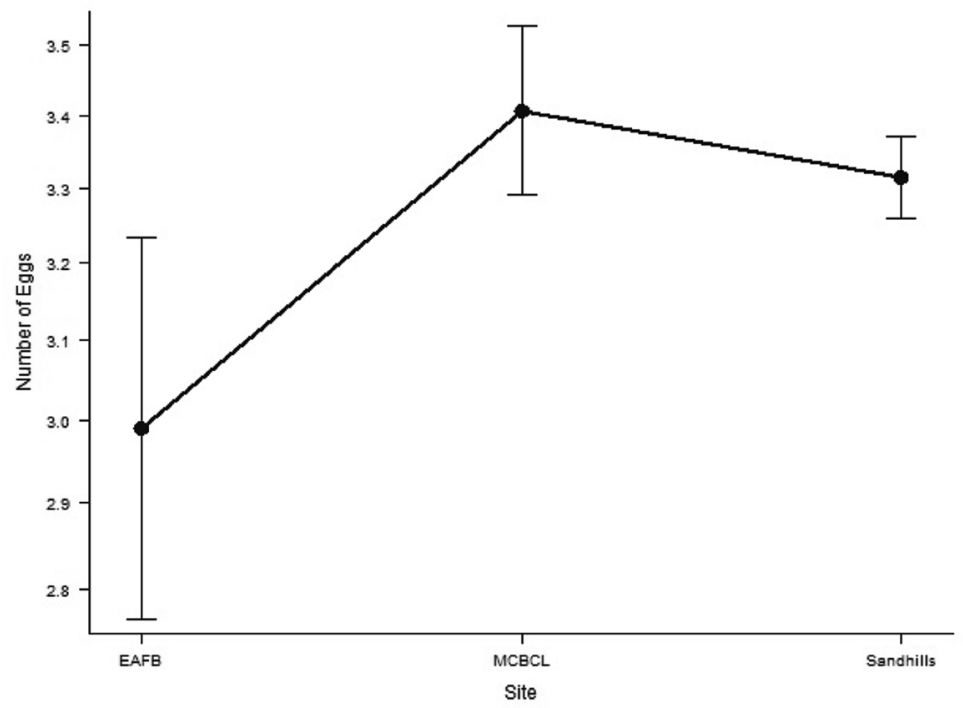

Figure 3. The number of eggs (clutch size) was larger at the two northernmost sites (coastal Marine Corps Base Camp Lejeune and the inland Sandhills site) compared to Eglin Air Force Base in coastal Florida. Estimates are predicted values from the highest ranked model with $95 \%$ confidence intervals

3. ábra A tojások száma (fészekaljméret) a két északi mintaterületen (Lejeune haditengerészeti bázis és homokdombok) nagyobb volt az Eglin légierő bázisnál tapasztaltakhoz képest. A becslések a lejobbnak értékelt modellből prediktált értékek, 95\%-os konfidencia intervallumokkal. A vízszintes tengelyen olvashatók az egyes mintaterületek: Eglin légierő bázis (EAFB), Lejeune haditengerészeti bázis (MCBCL), homokdombok (SH) 


\begin{tabular}{|r|c|r|r|r|c|}
\hline Model (Fledglings) & $K$ & \multicolumn{1}{|c|}{ AICC } & Delta_AICC & \multicolumn{1}{c|}{ LL } & Cum.Wt \\
\hline Site + Group Size + Age + Bird ID & $\mathbf{6}$ & $\mathbf{4 8 8 5 . 5 3 8}$ & $\mathbf{0}$ & $\mathbf{- 2 4 3 6 . 7 6}$ & $\mathbf{1}$ \\
\hline Group Size + Age + Bird ID & 4 & 4924.064 & 38.525 & -2458.03 & 1 \\
\hline Site + Group Size + Bird ID & 5 & 5048.455 & 162.917 & -2519.22 & 1 \\
\hline Site + Age + Bird ID & 5 & 5061.142 & 175.604 & -2525.57 & 1 \\
\hline Age + Bird ID & 3 & 5089.991 & 204.453 & -2541.99 & 1 \\
\hline Group Size + Bird ID & 3 & 5090.812 & 205.273 & -2542.40 & 1 \\
\hline Site + Bird ID & 4 & 5280.114 & 394.576 & -2636.05 & 1 \\
\hline Bird ID & 2 & 5307.040 & 421.501 & -2651.52 & 1 \\
\hline
\end{tabular}

Table 4. Comparison of models examining factors that affect the number of fledglings produced in Red-cockaded Woodpeckers ( $n=5,428)$. Individual bird identity (Bird ID) was included as a random factor. LL is the log likelihood, Cum. Wt is the cumulative Akaike weight of each model

4. táblázat $A$ kokárdás harkály kirepülési számát $(n=5428)$ befolyásoló faktorokat vizsgáló modellek összehasonlítása. A madarak egyedi azonosítója (Bird ID) random faktorként volt kezelve. Az LL log likelihood-ot jelent, a Cum. Wt pedig az egyes modellek Akaike (AIC, Akaike információs kritérium) súlyát jelenti

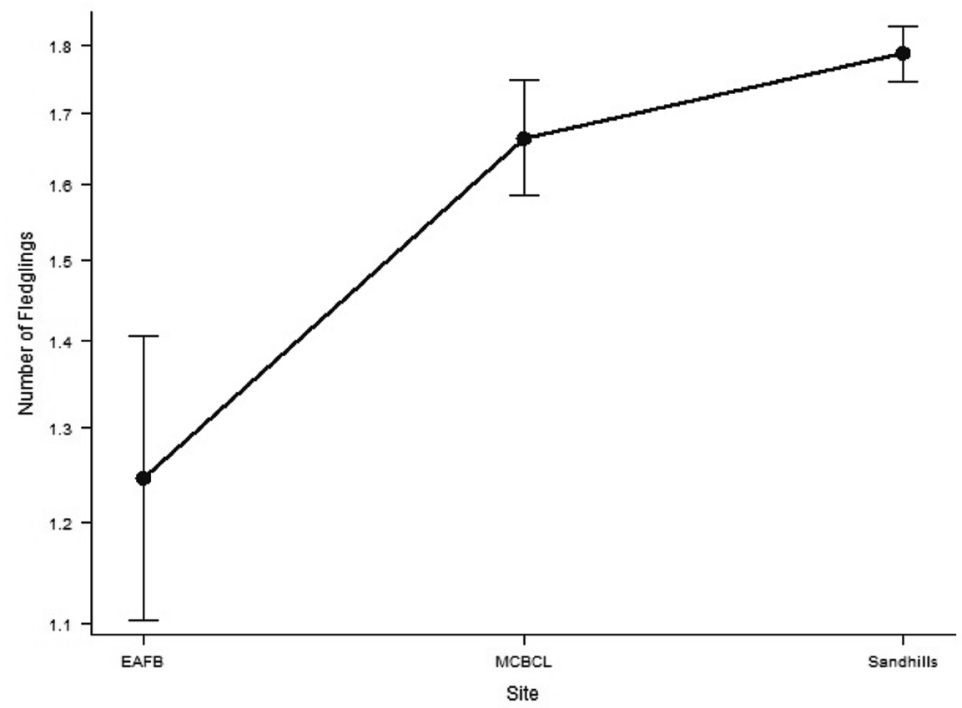

Figure 4. The mean number of fledglings was larger at the two northernmost sites (coastal Marine Corps Base Camp Lejeune and the inland Sandhills study site) compared to the coastal site in Florida (Eglin Air Force Base). Estimates are predicted values from the highest ranked model with $95 \%$ confidence intervals

4. ábra A kirepült egyedek átlagos száma magasabb volt a két északi mintaterületen (Lejeune haditengerészeti bázis és homokdombok). A becslések a lejobbnak értékelt modellből prediktált értékek, 95\%-os konfidencia intervallumokkal. A vízszintes tengelyen olvashatók az egyes mintaterületek: Eglin légierő bázis (EAFB), Lejeune haditengerészeti bázis ( $M C B C L)$, homokdombok (SH) 


\begin{tabular}{|c|c|c|c|c|c|}
\hline Model (Lay Date) & K & $\mathrm{AICC}$ & Delta_AlCc & $L L$ & Cum.Wt \\
\hline Site + Age + Mate's Age + Microsite & 5 & 2440.191 & 0 & -1215.09 & 0.891347 \\
\hline Age + Mate's Age + Microsite & 4 & 2444.400 & 4.209 & -1218.19 & 1 \\
\hline Site + Mate's Age + Microsite & 4 & 2809.978 & 369.787 & -1400.98 & 1 \\
\hline Mate's Age + Microsite & 3 & 2813.886 & 373.695 & -1403.94 & 1 \\
\hline Site + Age + Microsite & 4 & 3407.092 & 966.901 & -1699.54 & 1 \\
\hline Age + Microsite & 3 & 3410.560 & 970.369 & -1702.28 & 1 \\
\hline Microsite & 2 & 4045.547 & 1605.356 & -2020.77 & 1 \\
\hline Site + Microsite & 3 & 4042.444 & 1602.253 & -2018.22 & 1 \\
\hline
\end{tabular}

Table 5. Comparison of models examining factors that affect Red-cockaded Woodpecker lay date $(n=5,215)$. Microsite (geographic location within each study site) was included as a random factor. LL is the log likelihood, Cum. Wt is the cumulative Akaike weight of each model

5. táblázat A kokárdás harkály tojásrakási dátumát $(\mathrm{n}=5215)$ befolyásoló faktorokat vizsgáló modellek összehasonlítása. A vizsgálati területen belüli pozíció (Microsite) random faktorként volt kezelve. Az LL log likelihood-ot jelent, a Cum. Wt pedig az egyes modellek Akaike (AIC, Akaike információs kritérium) súlyát jelenti

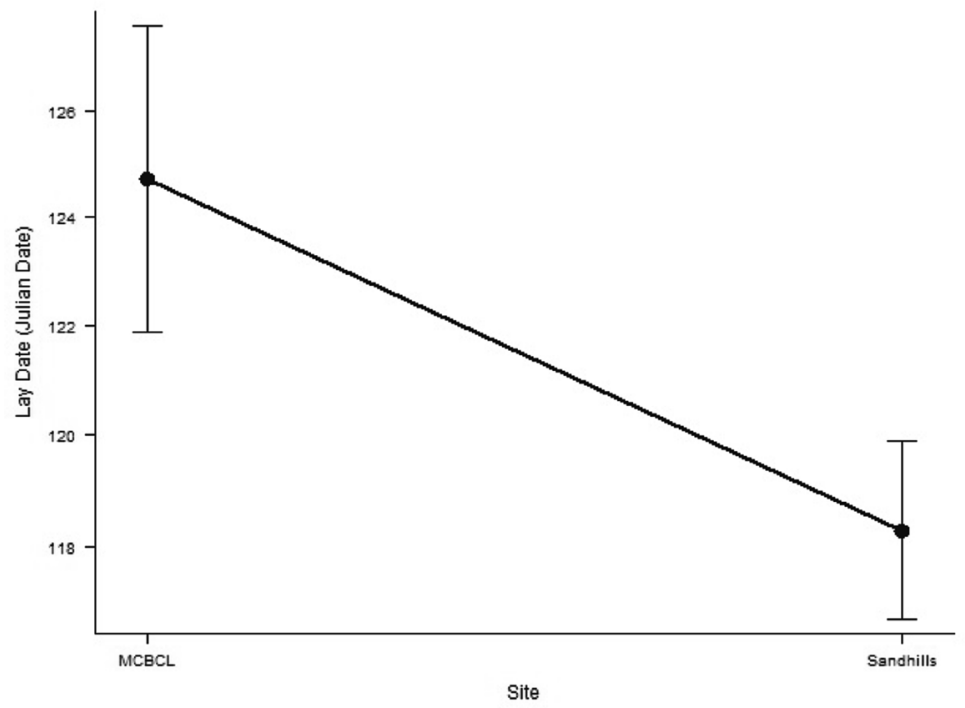

Figure 5. Lay dates were larger (later) at coastal Marine Corps Base Camp Lejeune when compared to the inland study site (Sandhills). Estimates are predicted values from the highest ranked model with $95 \%$ confidence intervals

5. ábra A tojásrakás későbbre esett a Lejeune haditengerészeti bázison a homokdombokhoz képest. A becslések a lejobbnak értékelt modellből prediktált értékek, 95\%-os konfidencia intervallumokkal. A vízszintes tengelyen olvashatók az egyes mintaterületek: Lejeune haditengerészeti bázis (MCBCL), homokdombok (SH) 


\begin{tabular}{|r|r|r|r|r|c|}
\hline Model (Brood loss) & $K$ & \multicolumn{1}{|c|}{ AlCC } & Delta_AICC & \multicolumn{1}{c|}{$L L$} & Cum.Wt \\
\hline Site + Territory & $\mathbf{4}$ & $\mathbf{5 6 3 5 . 9 6 4}$ & $\mathbf{0}$ & $\mathbf{- 2 8 1 3 . 9 8}$ & $\mathbf{1}$ \\
\hline Territory & 2 & 5692.196 & 56.232 & -2844.10 & 1 \\
\hline
\end{tabular}

Table 6. Comparison of models examining factors that affect Red-cockaded Woodpecker brood loss $(n=7,793)$. Territory was treated as a random factor. LL is the log likelihood, Cum. Wt is the cumulative Akaike weight of each model

6. táblázat A kokárdás harkály fészekalj-veszteségét $(\mathrm{n}=7793)$ befolyásoló faktorokat vizsgáló modellek összehasonlítása. A territórium (territory) random faktorként volt kezelve. Az LL log likelihood-ot jelent, a Cum. Wt pedig az egyes modellek Akaike (AIC, Akaike információs kritérium) súlyát jelenti

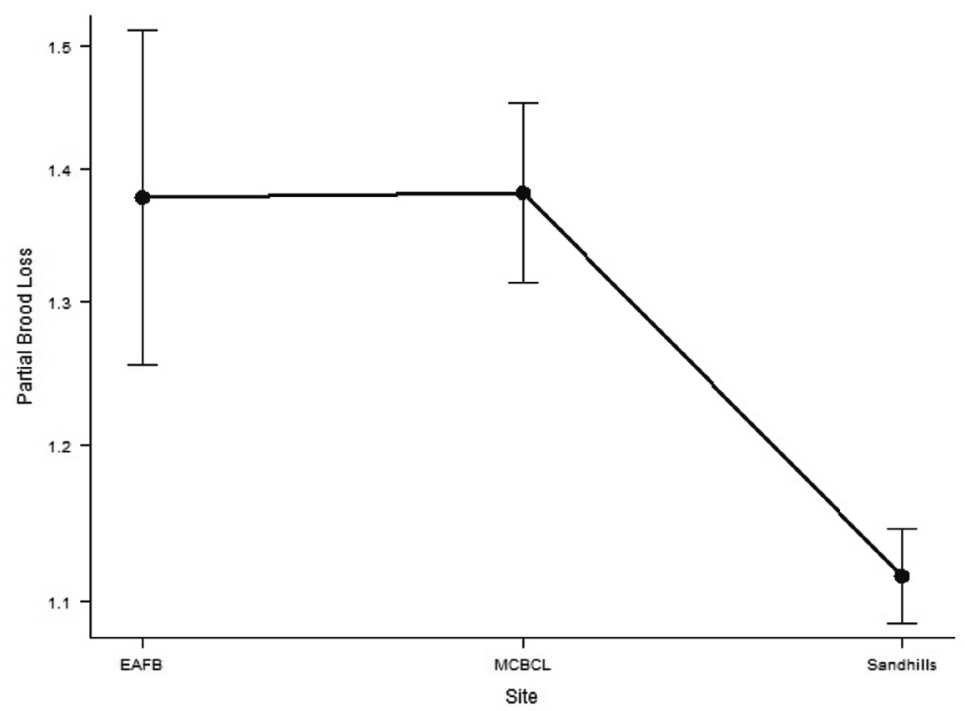

Figure 6. The amount of brood loss was lower at the inland study site (Sandhills) when compared to the two coastal sites (Marine Corps Base Camp Lejeune and Eglin Air Force Base). Estimates are predicted values from the highest ranked model with $95 \%$ confidence intervals

6. ábra A fészekalj-veszteség a homokdombok elnevezésű vizsgálati területen alacsonyabb volt a másik két mintaterülethez képest. A becslések a lejobbnak értékelt modellből prediktált értékek, 95\%-os konfidencia intervallumokkal. A vízszintes tengelyen olvashatók az egyes mintaterületek: Eglin légierő bázis (EAFB), Lejeune haditengerészeti bázis (MCBCL), homokdombok (SH) 


\section{Discussion}

Among the three Red-cockaded Woodpecker populations studied, there was ample evidence of life history variation suggesting adaptation to different conditions. The coastal populations had larger group sizes and longer lifespans compared to the inland Sandhills site, suggesting that survival is better in coastal areas than at inland sites. Group size for Red-cockaded Woodpeckers has been found to be positively correlated with fledging success (Conner et al. 2004), but the coastal populations experienced high brood loss despite having the largest group sizes. This could indicate that reproduction is more limited by highly variable environmental factors in coastal areas. An increase in parental care is thought to occur in order to prevent reduced survival of offspring due to adverse environmental conditions (Clutton-Brock 1991). This limitation on the number of young that survive could be a direct factor of inclement weather or due to the parents and helpers not being able to exert enough effort to properly feed and care for fledglings so that they all thrive. For example, this could be a matter of reproductive investment, with effort being limited such that fewer young survive when conditions are poorer (i.e. the same effort results in less food brought to the nest under poor conditions). Coastal storms can form from hurricanes, wave developments, depressions, and severe local storms, with the most severe damage coming from hurricanes. The southern states may experience fewer storms than the northern states, but the intensity of storms in the southern states is greater (Mather et al. 1964). Engstrom and Evans (1990) reported a $25 \%$ mortality in cavity trees during a hurricane year and this mortality rate was expected to be at least an order of magnitude greater than in a year in which a hurricane did not occur. Reduction of available cavities and increase in competition for cavities could force Red-cockaded Woodpeckers to roost outside of cavities and increase exposure to weather and predators, therefore weakening them or increasing chances of mortality (Engstrom \& Evans 1990). The late lay date and high brood loss even with a large number of helpers could indicate that environmental factors, such as the highly variable coastal weather at Marine Corps Base Camp Lejeune, limited the number of nestlings that survived to fledging.

The southern, coastal Florida population at Eglin Air Force Base differed from the two northern populations in exhibiting lower clutch sizes and number of young fledged. The two northern populations were similar in these respects, suggesting a north-south gradient, in addition to the coastal-inland gradient discussed above, one that specifically impacts productivity. This suggests a geographic gradient in availability of resources as low food availability favors a smaller clutch and brood sizes (Ricklefs 1980, Badyaev \& Ghalambor 2001). Lower food availability may be due to decreased seasonality from north to south (Ricklefs 1980). Eglin Air Force Base contains more old growth forest compared to the other sites (Varner \& Kush 2004), suggesting that poor habitat is not responsible for this pattern. However, Eglin Air Force Base is known to be a low productivity site in terms of forestry metrics, so this likely is a factor (Provencher et al. 2001). Nevertheless, we cannot draw firm conclusions about how latitudinal gradients affect Red-cockaded Woodpecker traits given the limited number of sites in our study.

Lay dates were earlier in the Sandhills site compared to Marine Corps Base Camp Lejeune, which suggests differences in spring arrival between inland and coastal areas, as has been found elsewhere (Nilsson \& Källander 2006). Group sizes were the smallest and 
lifespans were shortest at the inland site (Sandhills), which may indicate that there is increased predation on adults or otherwise harsher conditions away from the coast.

These three sites in the southeastern United States have shown how different the needs of isolated populations can be within a species. To effectively manage populations, each site would benefit from conducting a study about the specific life history trade-offs a population employs. Knowing and monitoring life history traits for these managed populations can allow management efforts to be assessed by how they affect traits, or managers can focus on improving certain traits. For example, number of adults per group is associated with territory quality (Heppell et al. 1994, Conner et al. 2001, McKellar et al. 2014) and may be used as a secondary measure of quality, along with habitat data. Additionally, adding new territories and cavities can temporarily decrease group sizes as helpers move to the new territories (Walters 1991), so keeping track of group sizes can help managers assess the need for new territories. Many studies monitor reproductive traits such as clutch size or number fledged, and these traits can help explain population dynamics and be indicators of overall population health.

\section{Acknowledgements}

This work was supported by the National Science Foundation Doctoral Dissertation Improvement Grant under number DEB 1311398. We would also like to thank field personnel and the Walters lab at Virginia Tech.

\section{References}

Anderson, D. R. 2008. Model-based inference in the life sciences: a primer on evidence. - Springer, New York, NY

Badyaev, A. V. \& Ghalambor, C. K. 2001. Evolution of life histories along elevational gradients: trade-off between parental care and fecundity. - Ecology 82: 2948-2960. DOI: 10.2307/2679973

Bates, D., Maechler, M., Bolker, B. \& Walker, S. 2015. Fitting linear mixed-effects models using lme4. Journal of Statistical Software 67: 1-48.

Bears, H., Martin, K. \& White, G. C. 2009. Breeding in high-elevation habitat results in shift to slower life-history strategy within a single species. - Journal of Animal Ecology 78: 365-375. DOI: 10.1111/j.1365-2656.2008.01491.x

Blanc, L. A. \& Walters, J. R. 2008. Cavity-nest webs in a longleaf pine ecosystem. - The Condor 110: 80-92. DOI: $10.1525 /$ cond.2008.110.1.80

Burnham, K. P. \& Anderson, D. R. 2002. Model selection and multimodel inference: a practical information-theoretic approach. $2^{\text {nd }}$ ed. - Springer, New York, NY

Carter III. J., Stamps, R. T. \& Doerr, P. D. 1983. Status of the Red-cockaded Woodpecker in the North Carolina Sandhills. - Red-cockaded Woodpecker symposium II. Florida Game and Fresh Water Fish Commission, Tallahassee, FL, pp. 24-29.

Clutton-Brock, T. H. 1991. The evolution of parental care. - Princeton University Press

Conner, R. N., Rudolph, D. C. \& Walters, J. R. 2001. The Red-cockaded Woodpecker: Surviving in a firemaintained ecosystem. - University of Texas Press, Austin, TX.

Conner, R. N., Saenz, D., Schaefer, R. R., McCormick, J. R., Rudolph, D. C. \& Burt, D. B. 2004. Group size and nest success in Red-cockaded Woodpeckers in the West Gulf Coastal Plain: helpers make a difference. - Journal of Field Ornithology 75: 74-78. DOI: 10.1648/0273-8570-75.1.74

Engstrom, R. T. \& Evans, G. W. 1990. Hurricane damage to Red-cockaded Woodpecker (Picoides borealis) cavity trees. - The Auk 107: 608-610.

Harding, S. R. \& Walters, J. R. 2004. Dynamics of cavity excavation by Red-cockaded Woodpeckers. In: Costa, R. \& Daniels, S. J. (eds.) Red-cockaded Woodpecker: Road to Recovery - Hancock House Publishing, Blaine, WA., pp. 412-422.

Heppell, S. S., Walters, J. R. \& Crowder, L. B. 1994. Evaluating management alternatives for Red-cockaded Woodpeckers: A modeling approach. 
- Journal of Wildlife Management 58: 479-487. DOI: $10.2307 / 3809319$

Hoyt, J. S. \& Hannon, S. J. 2002. Habitat associations of Black-backed and Three-toed Woodpeckers in the boreal forest of Alberta. - Canadian Journal of Forest Research 32: 1881-1888. DOI: 10.1139/ x02-109

James, F. C., Hess, C. A. \& Kufrin, D. 1997. Species-centered environmental analysis: indirect effects of fire history on Red-cockaded Woodpeckers. - Ecological Applications 7: 118-129. DOI: 10.2307/2269411

Lack, D. 1947. The significance of clutch-size. - Ibis 89: 302-352. DOI: 10.1111/j.1474-919X.1947. tb04155.x

Lennartz, M., Hooper, R. \& Harlow, R. 1987. Sociality and cooperative breeding of Red-cockaded Woodpeckers, Picoides borealis. - Behavioral Ecology and Sociobiology 20: 77-88.

Letcher, B. H., Priddy, J. A., Walters, J. R. \& Crowder, L.B. 1998. An individual-based, spatially-explicit simulation model of the population dynamics of the endangered Red-cockaded Woodpecker, Picoides borealis. - Biological Conservation 86: 1-14. DOI: 10.1016/S0006-3207(98)00019-6

Ligon, J. D. 1970. Behavior and breeding biology of the Red-cockaded Woodpecker. - The Auk 87: 255278. DOI: $10.2307 / 4083919$

Linden, M. \& Møller, A. P. 1989. Cost of reproduction and covariation of life history traits in birds. Trends in Ecology \& Evolution 4: 367-371. DOI: 10.1016/0169-5347(89)90101-8

Mather, J. R., Adams III. H. \& Yoshioka, G. A. 1964. Coastal storms of the eastern United States. - Journal of Applied Meteorology 3: 693-706. DOI: 10.1175/1520-0450(1964)003<0693:CSOTEU>2.0. $\mathrm{CO} ; 2$

McKellar, A. E., Kesler, D. C., Mitchell, R. J,. Delaney, D. K. \& Walters, J. R. 2014. Geographic variation in fitness and foraging habitat quality in an endangered bird. - Biological Conservation 175: 52-64. DOI: 10.1016/j.biocon.2014.04.007

Montague-Drake, R. M., Lindenmayer, D. B. \& Cunningham, R. B. 2009. Factors affecting site occupancy by woodland bird species of conservation concern. - Biological Conservation 142: 28962903. DOI: 10.1016/j.biocon.2009.07.009

Nilsson, J-Å. \& Källander, H. 2006. Leafing phenology and timing of egg laying in Great Tits Parus major and Blue Tits $P$. caeruleus. - Journal of Avian Biology 37: 357-363. DOI: 10.1111/j.2006.09088857.03604.x

Provencher, L., Herring, B. J., Gordon, D. R., Rodgers, H. L., Tanner, G. W., Hardesty, J. L., Brennan, L. A. \& Litt, A. R. 2001. Longleaf pine and oak responses to hardwood reduction techniques in fire-suppressed sandhills in northwest Florida. - Forest Ecology and Management 148: 63-77. DOI: 10.1016/S03781127

R Core Team 2014. R: A language and environment for statistical computing. - R Foundation for Statistical Computing, Vienna, Austria

Ricklefs, R. E. 1980. Geographical variation in clutch size among passerine birds: Ashmole's hypothesis. - The Auk 97: 38-49.

Schaefer, R. R., Conner, R. N., Rudolph, D. C. \& Saenz, D. 2004. Red-cockaded Woodpecker nestling provisioning and reproduction in two different pine habitats. - Wilson Bulletin 116: 31-40. DOI: $\quad 10.1676 / 0043-5643(2004) 116[0031: R W N-$ PAR]2.0.CO;2

Stearns, S. C. 1976. Life-history tactics: a review of the ideas. - The Quarterly Review of Biology 51(1): 3-47.

Trainor, A., Walters, J., Morris, W., Sexton, J. \& Moody, A. 2013. Empirical estimation of dispersal resistance surfaces: a case study with Red-cockaded Woodpeckers. - Landscape Ecology 28: 755-767. DOI: 10.1007/s10980-013-9861-5

Varner, J. M., III. \& Kush, J. S. 2004. Remnant oldgrowth longleaf pine (Pinus palustris Mill.) savannas and forests of the southeastern USA: Status and threats. - Natural Areas Journal 24: 141-149.

Walters, J., Robinson, P., Starnes, W. \& Goodson, J. 1995. The relative effectiveness of artificial cavity starts and artificial cavities in inducing the formation of new groups of Red-cockaded Woodpeckers. - In: Kulhavy, D. L., Hooper, R. G. \& Costa, R. (eds.) Red-cockaded Woodpecker: recovery, ecology and management. - Center for Applied Studies in Forestry, College of Forestry, Stephen F. Austin State University, Nacogdoches, Texas, USA, pp. 367-371.

Walters, J. R. 1991. Application of ecological principles to the management of endangered species: the case of the Red-cockaded Woodpecker. - Annual Review of Ecology and Systematics 22: 505-523.

Walters, J. R., Copeyon, C. K. \& Carter, J. H. 1992. Test of the ecological basis of cooperative breeding in Red-cockaded Woodpeckers. - The Auk 109: 9097. DOI: $10.2307 / 4088269$

Walters, J. R., Doerr, P. D. \& Carter, J. H. 1988. The cooperative breeding system of the Red-cockaded Woodpecker. - Ethology 78: 275-305. DOI: 10.1111/j.1439-0310.1988.tb00239.x

Zera, A. J. \& Harshman, L. G. 2001. The physiology of life history trade-offs in animals. - Annual Review of Ecology and Systematics 32: 95-126.

Zwicker, S. M. \& Walters, J. R. 1999. Selection of pines for foraging by Red-cockaded Woodpeckers. - The Journal of Wildlife Management 63(3): 843-852. DOI: $10.2307 / 3802797$ 